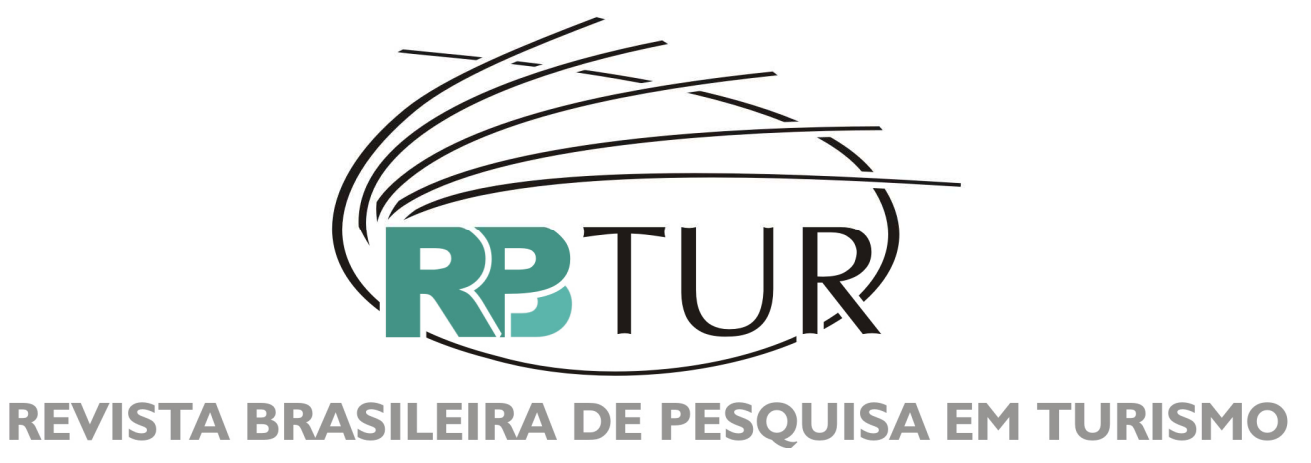

\title{
EDITORIAL
}

\section{EDITORS PAGE}

O presente número da Revista Brasileira de Pesquisa em Turismo RBTur marca a quinta revista editada por esta equipe.

Nele, destacamos alguns dos diferentes métodos e metodologias de pesquisa que podem ser aplicadas ao estudo do Turismo, tão diversas quanto diverso é o fenômeno que nos ocupa.

O Turismo pode ser abordado mediante pesquisa qualitativa ou quantitativa, pode ser analisado com o método dialético para mostrar as suas contradições, ou com o método hipotético dedutivo para comprovar hipóteses sobre relações causa-efeito.

Podem ser usados tanto o procedimento histórico, quanto o monográfico, o comparativo, o estatístico, o funcionalista e o estruturalista indistintamente ou combinados, em função do que se quer estudar.

Como técnicas da metodologia de pesquisa, pode ser adotado variado instrumental, tais como questionários, entrevistas, até histórias de vida, pesquisa bibliográfica, documental, pode se fazer observação, observação participante ou etnografia, cujos resultados também podem ser analisados de variadas formas.

No artigo do professor Ascanio vemos a aplicação da análise de conteúdo, para pesquisar a influência dos meios de comunicação na percepção de um problema na área de Turismo. Embora as fontes de dados remontem a 
duas décadas, apresenta grande atualidade, no que pode estimular outros pesquisadores a realizar estudos comparativos com a nossa atualidade.

O estudo de Argôlo e Bomfim utiliza a análise de discurso, não se restringindo apenas aos conteúdos dos textos (palavras-chave), mas ao sentido das falas dos entrevistados para analisar o planejamento de Turismo nas comunidades da Costa do Cacau.

No artigo de Beares e Cabral, que estudam a hospitalidade em comunidades tradicionais, podem ser identificados métodos provenientes da antropologia e da psicologia social, tais como a etnografia e os estudos de percepção.

Estudos de marketing são aplicados ao Turismo por Miguel e Silveira para avaliar o estado da arte de um destino turístico do estado de Santa Catarina.

O estudo de Sagi mostra o ecletismo na utilização de métodos e procedimentos, trabalhando com pesquisa bibliográfica, documental, questionários e observação.

Para encerrar, uma crítica a um livro eclético que fala em patrimônio, história, turismo e sociedade e uma crônica de um evento que reuniu turismólogos em um congresso de antropologia.

Este número reafirma a riqueza do turismo enquanto objeto de pesquisa a partir das mais diversas abordagens e formações, e suas infinitas interfaces com outras esferas de atuação do homem em sociedade. 